\title{
PERAN KEPALA SEKOLAH DALAM MELAKSANAKAN SUPERVISI KLINIS DI SEKOLAH DASAR NEGERI CATAK GAYAM 02 MOJOWARNO JOMBANG
}

\author{
Rofiatul Hosna \\ Dosen Universitas Hasyim Asy'ari Jombang/Direktur Pascasarjana \\ Email: rofiatulhosna@gmail.com
}

\begin{abstract}
The function of education is to prepare the students in order to reach the national goal of education. The Headmaster has a big responsibity to receive, to keep, and to do educational program in order to reach the goals. The efforts done in elementary School (SD) Negeri Catak Ayam 02. This research has been done in order to 1) analyze the headmaster in doing clinical supervision, 2) to encourage the teachers to improve their works, 3) to help solving the problems of te teachers in teaching, and 4) to analyze the problems in doing clinical supervision. The research has been done through qualitative approach, it is done by using case study. The instruments are headmaster, teachers, and students. The result shows that the clinical supervision has been done by giving encouragement, help teachers in solving the problems, solving the problems clinical supervision by giving practical teaching, doing interactive communication, using rest time better, and giving persuasif explanation to teachers and students.
\end{abstract}

Keywords : the headmaster role, clinical supervision, elementary school.

\begin{abstract}
Abstrak
Pendidikan berfungsi menyiapkan peserta didik bagi peranannya dimasa depan baik sebagai individu maupun sebagai warga tenaga kerja, sebagai pencapaian tujuan pendidikan nasional, maka sekolah merupakan lembaga pendidikan dalam penyelenggaraannya harus menjabarkan pendidikan nasional itu dalam kegiatannya. Kepala sekolah mempunyai tanggung jawab yang cukup besar dalam menerima dan memelihara serta melaksanakan sebagai peraturan dan program pendidikan untuk mencapai tujuan pendidikan Nasional. Penelitian ini bertujuan: (1) menganalisa kepala sekolah dalam melaksanakan supervisi klinis, (2) dalam memberi dorongan guru untuk meningkatkan kinerjanya, (3) membantu guru mengatasi masalah, dan (4) kendala-kendala melaksanakan supervisi klinis. Pendekatan penelitian kualitatif dengan jenis penelitian studi kasus. Subyek penelitian kepala sekolah, guru, dan siswa. Hasil penelitian bahwa pelaksanaan supervisi klinis denga cara memberikan dorongan, membantu memecahkan masalah, dan mengatasi kendalakendala pelaksanaan supervisi klinis dengan mengikut sertakan guru pada pelatihan, mengutamakan komunikasi secara kekeluargaan, hati-
\end{abstract}


176 | TAZKIR: Jurnal Penelitian Ilmu-ilmu Sosial dan Keislaman

Vol. 02 No. 2 Desember 2016

hati dalam mengambil langkah, menggunakan jam istirahat, memberikan penjelasan kepada guru dan siswa secara persuasif.

Kata Kunci : Peran Kepala Sekolah, Supervisi Klinis, Sekolah Dasar Negeri.

\section{PENDAHULUAN}

Dengan pendidikan suatu bangsa berpeluang meningkatkan harkat dan martabat bangsa dalam tata pergaulan masyarakat di dunia terlebih pada era persaingan global dewasa ini. Sejalan dengan hal itu, Indonsia sebagai salah satu negara dalam tatacara pergaulan dunia, berupaya untuk mewujutkan sistim dan iklim pendidikan yang demokratis dan bermutu guna membentuk watak serta peradaban bangsa yang bermartabat dalam rangka mencerdaskan kehidupan bangsa, bertujuan untuk berkembangnya potensi peserta didik agar menjadi manusia yang beriman, bertakwa kepada Tuhan Yang Maha Esa berakhlak mulia, sehat, berilmu, cakap, kreatif, mandiri, dan menjadi warga yang demokratis serta bertanggung jawab. Berkaitan dengan peran srtategis tersebut Siagian (1995) berpendapat bahwa sukses tidaknya pengelolaan suatu organisasi sangat tergantung pada kemampuan pimpinannya untuk menggerakkan seluruh sumberdaya, sehingga penggunaannya efektif dan efisien. Demikian pula Thoha ${ }^{1}$ menjelaskan bahwa suatu organisasi gagal atau berhasil, sebagian besar ditentukan olek faktor kepemimpinan.

\section{TINJAUAN PUSTAKA}

Pendidikan berfungsi menyiapkan peserta didik bagi peranannya dimasa depan baik sebagai individu maupun sebagai warga tenaga kerja, sebagai pencapaian tujuan pendidikan nasional, maka sekolah merupakan lembaga pendidikan dalam penyelenggaraannya harus menjabarkan pendidikan nasional itu dalam kegiatannya. Kemenag maupun kemendikbud mempunyai peran yang utama untuk menjabarkan tujuan pendidikan Nasional tersebut kedalam berbagai peraturan, kurikulum, program, maupun sarana sebagai fasillitas bagi pelaksanaan pendidikan dan pengajaran disekolah. Oleh karena itu baik di tingkat SD, SMP maupun ditingkat SMA, SMK, kepala sekolah mempunyai tanggung jawab yang cukup besar dalam menerima dan memelihara serta melaksanakan sebagai peraturan dan program pendidikan untuk mencapai tujuan pendidikan Nasional. Diantara tugas dan tanggung jawabnya adalah membantu guru-guru dalam memperbaiki kinerja serta menumbuhkan inovasi

1Thoha, Mifta. Kepemimpinan Dalam Manajemen. (Jakarta: Rajawali Press, 1995), hlm. 1. 
dalam mengemban tugas dan tanggungjawabnya disamping itu juga menbantu dan memotivasi guru agar para guru mampu menciptakan situasi belajar mengajar yang baik.

Lucio $^{2}$ mengemukakan ada enam jenis tanggung jawab supervisor secara umum yaitu sebagai: 1) Perencanaan, merupakan proses penentuan tujuan atau sasaran yang hendak dicapai dan menetapkan jalan dan sumber yang diperlukan untuk mencapai tujuan itu seefisien dan seefektif mungkin, 2) administrator, kepala sekolah sebagai administrator bertanggung jawab atas penyelenggaraan administrasi suatu lembaga. Sebagai administrator mempunyai kemampuan dalam pengelolaan administrasi Kegiata Belajar Mengajar dan Bimbingan Konseling, mengelola administrasi kesiswaan, mengelola administrasi kepegawaian/ketenagaan, mengelola administrasi keuangan, administrasi sarana dan prasarana, administrasi persuratan, 3) supervisi, merupakan kegiatan mengkoordinasikan pekerjaan yang dilakukan orang lain, 4) mengembangkan kurikulum, membantu guru dalam menjabarkan kurikulum, mengingat kurikulum kita secara terus menerus dilakukan perubahan dan berupaya memasukkan muatan lokal yang sesuai dengan potensi lingkungan, 5) demonstrasi mengajar, seorang supervisor hendaknya selalu memberi contoh cara belajar mengajar yang lebih dengan menggunakan jam pelajaran yang tetap (mengajar sesuai dengan jadwal yang diperoleh dalam pembagian tugas mengajar), dan 6) riset pendidikan, kepala sekolah secara rutin mengadakan penelitian pendidikan dengan maksud untuk terus mengembangkan pendidikan kearah yang lebih baik.

Dari uraian di atas menunjukkan bahwa tanggung jawab seorang supervisor yang paling utama adalah berkenaan dengan kurikulum sekolah beserta faktor-faktor penunjang dan yang paling penting perlu mendapatkan perhatian adalah pelaksanaan kurikulum disekolah yaitu para guru. Sebab ditangan para gurulah terletak kunci penting dalam usaha untuk mencapai tujuan pendidikan nasional. Sebagai seorang guru yang memiliki tugas dan tanggung jawab cukup berat dalam mengemban misi pendidikan tentunya harus didukung oleh berbagai kemampuan. Kemampuan utama yang harus ada pada guru adalah kemampuan mengajar.

${ }^{2}$ Lucio, William H. \& McNeil, John D. Supervision in Throught and action. 3 id. Ed. (New York: McGrow-hill Book CO.), 1979. 
178 | TAZKIR: Jurnal Penelitian Ilmu-ilmu Sosial dan Keislaman

Vol. 02 No. 2 Desember 2016

Upaya kepala sekolah dalam menciptakan situasi kerja yang kondusif dapat dilaksanakan di Sekolah Dasar Negeri Catak Gayam 02, situasi kerja sekolah ini sangat menyenangkan, hubungan antar warga sekolah sangat baik, hal ini terlihat aktifitas sehari-hari komunikasi antara atasan dan bawahan berlangsung sangat akrab, setiap satu bulan sekali diadakan pertemuan (silaturrohmi) keluarga secara rutin dengan cara bergantian yang didalamnya diberi atau diadakan arisan keluarga, yang dapat mempertemukan keluarga sekolah, dan disitulah terjadinya pembauran yang tidak membedakan status dan tingkatan, dalam menjalankan tugasnya mereka bekerja dengan semangat dan penuh tanggung jawab sekalipun kepala sekolah sedang tidak berada di tempat. Sehingga tujuan sekolah yang telah ditetapkan akan dapat tercapai dengan baik.

Keberhasilan ini tidak terlepas dari peran seorang kepala sekolah dalam melaksanakan fungsinya sebagai supervisor dalam melaksanakan pembinaan melalui supervisi klinis sehingga dapat menciptakan situasi kerja yang kondusif. Untuk mengetahui seberapa jauh peran kepala sekolah tersebut diperlukan adanya suatu penelitian yang mendalam, sehingga melalui penelitian ini, peneliti dapat memperoleh sesuatu gambaran tentang perannya dalam melaksanakan supervisi klinis. Berdasarkan konteks penelitian diatas, peneliti akan mengungkap beberapa masalah antara lain: Tahapan-tahapan pelaksanaan supervisi klinis di Sekolah Dasar Negeri Catak Gayam 02, peran kepala sekolah dalam memberikan dorongnan kepada guru untuk meningkatkan kinerjanya, bagaimana tahapan-tahapan pelaksanaan supervisi klinis di Sekolah Dasar Negeri Catak Gayam 02, bagaimana peran kepala sekolah memberikan dorongan kepada guru untuk meningkatkan kinerjanya di Sekolah Dasar Negeri Catak Gayam 02 dan bagaimana peran kepala sekolah dalam membantu guru untuk memecahkan masalah di Sekolah Dasar Negeri Catak Gayam 02 serta kendala-kendala yang dihadapi dalam pelaksanaan supervisi klinis di Sekolah Dasar Negeri Catak Gayam 02.

Dari berbagai permasalahan yang akan diteliti, maka penelitian bertujuan untuk mendiskripsikan dan menganalisis tentang: tahapan-tahapan pelaksanaan supervisi klinis yang dilakukan kepala sekolah, peran kepala sekolah dalam memberikan dorongan kepada guru untuk meningkatkan kinerjanya, peran kepala sekolah dalam membantu guru untuk memecahkan masalah yang sedang dihadapi, kendala-kendala apa saja yang dihadapi dan dapat dijadikan sebagai dasar dan perbandingan bagi para peneliti, yang ingin melakukan penelitian 
lanjutan, sehingga dimukingkan hasil penelitian tentang peranan kepala sekolah dalam melaksanakan supervisi klinis dapat terus dikembangkan oleh peneliti berikutnya Secara praktis bagi kepala sekolah kegunaannya kepala sekolah dapat memahami fungsinya sebagai seorang supervisor dalam memberikan bantuan kepada guru, sehingga dapat melaksanakan tugasnya sebaik-baiknya dalam membantu memecahkan masalah, dan kepala sekolah memahami dalam memberikan dorongan kepada para guru, agar dapat terus berusaha untuk mengembangkan kemampuan profesionalnya. Kepala sekolah juga menyadari fungsinya guru dapat melihat fungsi kepala sekolah dalam membantu dirinya untuk memecakan masalah. Sedangkan bagi guru penelitian ini agar guru dapat melihat fungsi kepala sekolah dalam memberikan dorongan untuk selalu meningkatkan prestasinya, dan mengikut sertakan para guru, baik untuk mengembangkan kemampuannya dan memecahkan masalah yang sedang dihadapi. Bagi peneliti lain untuk penelitian lebih lanjut dengan aspek-aspek yang lebih kompleks.

Penelitian ini bertujuan: (1) menganalisa kepala sekolah dalam melaksanakan supervisi klinis, (2) dalam memberi dorongan guru untuk meningkatkan kinerjanya, (3) membantu guru mengatasi masalah, dan (4) kendala-kendala melaksanakan supervisi klinis.

\section{METODE PENELITIAN}

Bertolak dari orientasi kajian, penelitian ini dikategorikan sebagai penelitian kualitatif dengan menggunakan pendekatan hirtoris-sosiologis. Hal ini didasari dengan pertimbangkan bahwa penelitian ini menggambarkan bagaimana realitas yang terjadi pada peranan kepala sekolah dalam melaksanakan supervisi klinis yang terkait dengan situasi dan tuntutan keadaan. Atau dengan kata lain bahwa penelitian ini bermaksud mengungkapkan bahwa keadaan atau kondisi saat ini merupakan kelanjutan dari masa sebelumnya. Dengan pendekatan historis-sosiologis ini mengungkapkan realitas, sejarah, kondisi sosial masyarakat dan relevansinya dengan gerakan institusi keagamaan.

Menurut Jack R. Fraenkel dan Norman E Wallen (2005), dalam Yatim Riyanto dan Nurul Zuriah ${ }^{3}$ menjelaskan penelitian sejarah ialah penelitian yang secara eksklusif memfokuskan pada masa lalu. Penelitian ini mencoba

${ }^{3}$ Yatim Riyanto. Metodologi Penelitian Pendidikan Kualitatif. (Surabaya: UNESA University Press.), 2007,) hlm. 51. 
180 | TAZKIR: Jurnal Penelitian Ilmu-ilmu Sosial dan Keislaman Vol. 02 No. 2 Desember 2016

merekonstruksikan apa yang terjadi pada masa lalu dengan selengkapnya dan seakurat mungkin dan bisa menjelaskan mengapa hal itu terjadi.

Dari sisi perspektif teoritik, peneliti kualitatif pada dasarnya dapat digolongkan menjadi penelitian fenomenologi, interaksi simbolik, budaya etnometodologi dan studi kasus ${ }^{4}$. Perspektif studi kasus dalam penelitian ini untuk mengakses seminasi secara detail atau suatu latar penelitian, yaitu Sekolah Dasar Negeri Catak Gayam 02 Kabupaten Jombang.

Penelitian ini akan dilaksanakan di Sekolah Dasar Negeri Catak Gayam 02 Kabupaten Jombang yang merupakan salah satu sekolah yang terletak di pinggiran Kabupaten Jombang tepatnya di kecamatan Mojowarno dengan jarak kurang lebih $22 \mathrm{~km}$. Dari arah terminal Jombang ke barat $200 \mathrm{~m}$, yang kemudian menuju ke selatan dengan jarak 800 m,dan pada pertigaan belok kiri $200 \mathrm{~m}$ kanan jalan ditemukan masjid besar yang bersebelahan dengan lokasi penelitian peneliti.

Dari segi tujuan penelitian ini termasuk penelitian deskriptif yaitu metode yang berusaha mendeskripsikan kondisi obyek dan sisilah sejarah dan peran kepala sekolah dalam melaksanakan supervisi klinis di Sekolah Dasar Negeri Catak Gayam 02. Sistem pendidikan yang hendak dicapai. Sumber data terdiri dari kepala sekolah, dari sini diharapkan peneliti memperoleh informasiinformasi yang dapat dikembangkan pada informasi selanjutnya ke infotrmasi yang lain seperti Tata Usaha selaku pananggung jawab pelaksanaan kegiatan administrasi, serta staf-staf yang lain seperti wakil kepala sekolah, coordinator urusan serta guru bidang studi yang ada di sekolah ini.

Mengingat tujuan pengambilan sampel, informasi dalam penelitian ini untuk memperoleh informasi sebanyak-banyaknya, maka teknik penjaringan data yang digunakan adalah teknik bola salju (Snow Ball Sampling). Pengumpulan data dilakukan dengan beberapa teknik, yaitu: Observasi, wawancara dan dokumentasi. Wawancara adalah proses percakapan dengan maksud untuk mengkonstruksikan mengenai orang, kejadian, organisasi, motivasi, perasaan, dan sebagainya yang dilakukan pihak-pihak lain yaitu : Pewancara (interviewer) yang mengajukan pertanyaan dengan orang yang di wawancara (interviewee). Interview dapat digunakan untuk mengumpulkan data dimana diperlukan adanya penjelasan langsung tentang konteks atau area

${ }^{4}$ Bogdan \& Biklen, Qualitative Research For Education: an Introduction to Theory and Method. 1982, (United States Of America.) 
penelitian kepada responden. Wawancara mendalam pada penelitian kualitatif dipergunakan untuk mendapatkan data tentang, kegiatan kepala sekolah dalam membantu guru untuk memperbaiki kinerja melalui supervisi klinis.

Sedangkan observasi/pengamatan adalah melakukan penelitian langsung kelapangan dan mendapat kejadian, gerak/proses, oleh sebab itu ada dua cara Pengamatan sebagaimana dikatakan oleh Suharsimi Arikunto ${ }^{5}$ (Arikunto, 2006:230). Mendiskusikan format observasi, menjelaskan dengan contoh suatu kejadian dan gerak untuk setiap item dengan memahami apa yang harus dianalisis dan sebagaimana cara membuat catatan. Latihan mengamati sekaligus mencatat kejadian ini berupa simulasi, diamati salah seorang peserta calon pengamat menjadi modal. Sedangkan yang lain menjadi pengamat dan mengisi format kemudian hasilnya didiskusikan.

Observasi pengamat dilakukan dengan penginderaan langsung kondisi, situasi proses dan perilaku. Metode ini dilakukan untuk memperoleh gambaran dan data lapangan yang terkait dengan kondisi dan keadaan di Sekolah Dasar Negeri Catak Gayam 02 dalam kegiatan pembelajaran dan peran supervesor untuk membantu guru.

Teknik Dokumentasi disebut sebagai data pelengkap (supplemen) yang diperoleh melalui wawancara dan observasi. Disamping itu data administrartif ini dipergunakan sebagai pelengkap dalam mengumpulkan data lebih lanjut untuk mendukung hasil observasi dan wawancara, metode dokumentasi juga salah satu cara mencari data mengenai hal-hal atau variabel yang berupa catatan, transkrip, buku, notulen rapat, agenda dalam metode ini. Metode ini tidak begitu sulit, dalam arti apabila ada kekeliruan datanya masih tetap, belum berubah, artinya metode ini yang diamati bukan benda hidup tetapi benda mati.

Analisis data dari hasil pengumpulan data disini, merupakan tahapan yang penting dalam penyelesaian suatu kegiatan penelitian ilmiah, sebab data yang telah terkumpul bila tidak dianalisis hanya menjadi barang yang tidak bermakna, tidak berarti menjadi data yang mati, data yang tidak berbunyi. Oleh karena itu analisis data disini berfungsi untuk memberi arti makna dan nilai yang terkandung di data itu. Analisis data merupakan prosedur mengatur

${ }^{5}$ Suharsimi Arikunto, S. 2006. Prosedur Penelitian Suatu Pendekatan Praktik. (Jakarta: PT Cipta Karya., 20006), hlm. 230. 
182 | TAZKIR: Jurnal Penelitian Ilmu-ilmu Sosial dan Keislaman

Vol. 02 No. 2 Desember 2016

urutan data, mengorganisasikannya ke dalam suatu pola, kategori dan satuan uraian dasar'.

Dengan demikian teknik analisis data peneliti ini dilakukan sebagai berikut:

Teknik reduksi data yaitu proses penyelesaian, penilaian, penyederhanaan dan pengkategorian data mentah berupa catatan tertulis dilapangan. Reduksi data dimaksud untuk membuat ringkasan dan menelusuri tema, sehingga memudahkan pengorganisasian data dan keperluan analisis data penarikan kesimpulan, menurut Miles dan Huberman untuk memilih data sesuai dan bermakna7.

Penyajian data merupakan proses konstruki beberapa informasi yang komplek/pemaparan data-data kompleks disusun secara sistematis yang memperhatikan keeratan kaitan dalam data, dan sekaligus menggambarkan apa yang sebenarnya. Secara umum penyajian data dalam penelitian ini ditampilkan ke dalam bentuk teks normatif.

Penarikan kesimpulan fenomena yang menunjukkan keteraturan kondisi yang berulang-ulang, serta pola-pola yang dominan dan yang penting berpengaruh. Kesimpulan dalam tahap ini mula-mula tampak belum jelas dan menyeluruh, sifatnya sementara, kemudian berlanjut pada tingkatan menyeluruh dan jelas.

Pengecekan Keabsahan Temuan. Untuk menjamin keabsahan/kebenaran data dalam penelitian kualitatif, Lincoln dan Ghuha menyebutkan empat standar/kreteria utama guna menjadi keterpercayaan/kebenaran hasil penelitian kualitatif yaitu kredibilitas, trasferabilitas, dependabilitas, dan konfermabilitas. Dalam penelitian ini keempat kriteria tersebut digunakan agar hasil penelitian ini benar-benar memenuhi karakteristik penelitian kualitatif ${ }^{8}$.

Standar Kredibilitas (kepercayaan), kredibilitas dalam penelitian kualitatif agar hasil penelitian kualitatif dapat dipercaya oleh pembaca, dan juga dapat disetujui kebenarannya oleh partisipan yang diteliti. Adapun beberapa teknik

${ }^{6}$ Pathon Michael Quinn, Qualitatif Evaluation Methods. (Sage Publication. Baverly Hills., 2000), hlm. 260 .

${ }^{7}$ Milles \& Humerman, Analisis Data Kualitatif, (Bandung: Remaja Rosdakarya,, 1992), hlm. 16.

${ }^{8}$ Sanafiah Faesal, Penelitian Kualitatif Dasar-Dasar dan Aplikasi. (Malang: Yayasan Asih Asuh, 1990), hlm $31-33$. 
yang digunakan dalam memenuhi standar kredibilitas antara lain; 1) Peneliti berada dilapangan dalam waktu yang cukup memadai oleh Licon dan Guba disebut prologed engagmen. Sehingga diharapkan terciptanya pemahaman terhadap partisipan dan segala kegiatannya lebih memadai, 2) Melakukan triagulasi langkah ini dilakukan sebagai upaya verifikasi temuan dengan mengecek kebenarannya dari berbagai sumber. Di samping itu peneliti juga mengadakan cek silang (cross check), 3) Cek silang ini dimaksud untuk mengecek keabsahan data dengan menanyakan kembali pertanyaan yang sama dilain waktu kepada informan, 4) Melakukan peer debriefing, langkah ini peneliti lakukan dengan melihat kolegen yang cenderung bersikap kritis atas hasil dan proses peneliti yang dilakukan, dan juga yang mempunyai latar belakang disiplin ilmu sesuai dengan permasalahan yang diteliti yaitu kulturisasi kebudayaan Islam antara dogma dan paradigma, 5) Melakukan member cek, digunakan untuk mengetahui, seberapa akurat data tersebut, ia memaparkan hasil temuan selama penelitian untuk dicek kesesuaian dan keabsahan oleh yang dikenai penelitian ini.

Standar Transferabilitas (keteralihan). Standar transferabilitas hasil penelitian ditentukan dalam para pembaca penelitian. Kuncinya adalah seberapa kaya gambaran yang dipaparkan oleh peneliti terkait dengan setting penelitian ini.

Standar Dependabilitas (ketergantungan). Untuk menjamin bahwa hasil penelitian mampu dialih pahamkan antara peneliti dengan yang diteliti, maka penjelasan atau deskripsi harus panjang lebar, dan tebal (thick description). Sebagai penganti reliabilitas digunakan dependabilitas yang akan memungkinkan perubahan dan instabilitas ${ }^{9}$.

Menurut Bakri10 Dependabilitas dipakai untuk menilai jalannya proses penelitian yang ditempuh hingga berbentuk sebuah laporan skripsi. Seorang peniti perlu melakukan dependabilitas, agar temuan peneliti dapat dipertahankan dan dipertanggung jawabkan secara alamiah. Oleh karena itu peranan berbagai pihak sebagai dependen ouditor, seperti pembimbing, tementemen sejawat sangat diperlukan.

${ }^{9}$ Rochiati Wiriaatmadja, Metode Penelitian Tindakan Kelas. (Bandung. Remaja Rosdakarya, 2009), hlm. 162.

${ }^{10}$ Masykuri Bakri, Metode Penlitian Kualitatif Pendekatan Teoritis dan Praktis. (Jakarta: Nirmana Press, 2013), hlm. 71. 
184 | TAZKIR: Jurnal Penelitian Ilmu-ilmu Sosial dan Keislaman

Vol. 02 No. 2 Desember 2016

Standar Confirmablity (kepastian). Penelitian naturalistik/kualitatuf akan lebih menilai data yang memiliki konfirmabilitas dari pada objektivitas, yang dicapai dengan mengaudit proses penelitian ${ }^{11}$ Standar ini dimaksud untuk memeriksa keterkaitan antara data hasil penelitian dan informasi serta interprestasi dalam organisasi pelaporan skripsi yang didukung oleh berbagai materi yang tersedia.

\section{HASIL PENELITIAN DAN PEMBAHASAN}

\section{Hasil Penelitian}

Langkah-langkah Supervisi Klinis, Indikator satu tahap awal dalam pelaksanaan supervisi klinis kepala sekolah menciptakan suasana intim dan terbuka antara supervisor dan guru sebelum langkah-langkah selanjutnya dibicarakan, membicarakan rencana pelajaran yang telah dibuat oleh guru yang mencakup tujuan, bahan, kegiatan belajar mengajar, serta alat evaluasinya, mengidentifikasi komponen keterampilan (beserta indikatornya) yang akan dicapai oleh guru dalam kegiatan mengajar, misalnya guru menguasai keterampilan bertanya, Rencana Program Pembelajaran (RPP) yang akan observasi kepala sekolah sudah merupakan kurikulum sekolah dan sudah dikembangkan oleh guru yang akan di observasi, dan mengembangkan atau memilih instrumen observasi yang akan digunakan, merekam data dalam penampilan guru sesuai dengan persetujuan dan kesepakatan tentang keterampilan beserta indikatornya. Dua tahap observasi kelas guru mengajar berdasarkan komponen ketrampilan yang sudah disiapkan dalam pertemuan pendahuluan, Kepala sekolah mengamati dan mencatat atau merekam tingkah laku guru yang sedang mengajar, dan mencatat tingkah laku siswa dan interaksi dengan siswa.Tiga Tahap analisa data, kepala sekolah menganalisa hasil observasi tidak bersama guru dan dilaksanakan pada waktu senggang yaitu jam istirahat, hasil observasi dianalisa oleh kepala sekolah, untuk digunakan sebagai bekal diskusi bersama guru, selanjutnya kepala sekolah dapat mengetahui kekurangan/kelemahan guru yang harus diperbaiki. Tahap terakhir diskusi hasil observasi kepala sekolah menanyakan perasaan guru tentang apa yang dialaminya dalam mengajar secara umum, meriview tujuan pelajaran, meriview target keterampilan serta perhatian utama guru dalam mengajar, menanyakan perasaan guru tentang jalannya pelajaran berdasarkan target dan perhatian

\footnotetext{
${ }^{11}$ Rochiati Wiriaatmadja, Metode Penelitian...., hlm. 162.
} 
utamanya, menunjukkan serta mengkaji hasil observasi, supervisi yang diberikan bersifat bantuan dengan tujuan untuk meningkatkan keterampilan mengajar dan sikap profesional, menanyakan perasaan guru tentang proses dan hasil pelajaran tersebut, menyimpulkan hasil dengan melihat apa yang sebenarnya telah terjadi/tercapai, serta menentukan secara bersama rencana mengajar yang akan datang.

Peran kepala sekolah dalam memberikan dorongan kepada guru untuk meningkatkan kinerjanya yaitu dengan mengedepankan komunikasi kebawah, mengikut sertakan para guru dalam penataran atau pelatihan, memberi dorongan dan penghargaan secara efektif, menggunakan waktu belajar secara efektif di sekolah, dalam memotifasi selalu menggunakan pendekatan persuasif, sikap ibu kepala sekolah yang keibuan, penuh santun, dan kasih sayang dalam setiap memberikan motifasi bawahannya, kepala sekolah tidak pernah memaksakan bawahannya untuk melakukan sesuatu sesuai kehendaknya serta selalu memaafkan dan melupakan setiap kesalahan bawahannya serta melakukan perbaikan bersama-sama.

Kepala sekolah dalam membantu guru untuk memecahkan masalah yang dihadapi bahwa kepala sekolah sebagai seorang pemimpin berperilaku arif dan terbuka, dalam proses pemberian bantuan dalam memecahkan masalah berjalan sangat akrab dan santai, jika masalahnya sangat tertutup dilakukan hanya empat mata, kelapa sekolah sangat jeli terhadap guru yang mempunyai masalah, dan kepala sekolah memberi umpan kepada guru dengan menceritakan permasalahan yang pernah dihadapinya.

Kendala yang dihadapi dalam pelaksanaan supervisi klinis di Sekolah Dasar Negeri Catak Gayam 02 adalah kepala sekolah sering tugas diluar, persepsi guru yang negatif terhadap pelaksanaan supervisi klinis, adanya pengakuan siswa bahwa observasi kelas menakutkan untuk menghilangkan kecemasan siswa ibu guru memberi penjelasan bahwa ibu kepala sekolah ikut saat kita belajar ingin melihat kita dari dekat dan bersedia membantu jika ada kesulitan.

\section{Pembahasan Hasil Penelitian}

Pembahasan atas penemuan dalam penelitian ini berorientasi pada pengembangan teori supervisi pendidikan (supervisi klinis), serta panduan teknis supervisi pendidikan di Sekolah Dasar Negeri Catak Gayam 02 sesuai dengan fokus penelitian pembahasannya berturut-turut meliputi: (1) tahapan- 
186 | TAZKIR: Jurnal Penelitian Ilmu-ilmu Sosial dan Keislaman Vol. 02 No. 2 Desember 2016

tahapan pelaksanan supervisi klinis di Sekolah Dasar Negeri Catak Gayam 02, (2) kepala sekolah dalam memberikan dorongan kepada guru untuk meningkatkan kinerjanya, (3) kepala sekolah dalam membantu guru untuk memecahkan masalah yang sedang di hadapi, dan (4) kendala-kendala yang dihadapi dalam pelaksanaan supervisi klinis di Sekolah Dasar Negeri Catak Gayam 02 Kabupaten Jombang.

Dalam Pelaksanaan supervisi klinis kepala sekolah melakukan supervisi dalam kelas satu kali dalam semester dan supervisi temporer yang tidak terjadwal biasanya dilakukan di luar kelas biasanya dilihat dari piket dan pelaksanaannya sehari-hari, supervisi klinis ini di dukung sepenuhnya oleh semua guru, ini terbukti guru sangat antusias dan berusaha mengajar sebaik mungkin.

Kepala sekolahpun mengadakan refleksi terhadap pelaksanaan pembelajaran dan bertanya kepada guru dan memberikan kesan-kesan terhadap pelaksanaan pengajaran yang telah dilakukan. Kemudian kepala sekolah bersama dengan guru mengindentifikasi target-target yang sudah dicapai dan belum dicapai dalam pembelajaran dan memberikan penguatan terhadap guru, setelah itu kepala sekolah merencanakan dan memberikan pelatihan sekaligus menetapkan rencana dan menyarankan guru untuk mengikuti pelatihanpelatihan yang ada disekolah maupun diluar sekolah.

Tahapan-Tahapan Pelaksanaan Supervisi Klinis di Sekolah Dasar Negeri Catak Gayam 02 supervisi klinis adalah suatu proses pembimbingan dalam mengelola proses belajar mengajar yang bertujuan membantu guru menuju guru yang profesional, khususnya dalam penampilan mengajar yang dimulai dari pertemuan awal, observasi kelas, dan pertemuan akhir, yang dianalisis secara cermat, teliti dan obyektif untuk mendapatkan perubahan perilaku pengajar yang diharapkan.

Sebagaimana Ngalim dalam Jasmani dan Saiful Mustofa mengatakan supervisi klinis yaitu suatu aktifitas pembinaan yang direncanakan untuk membantu guru dan pegawai sekolah lainnya dalam melakukan pekerjaan mereka secara efektif. Pada dasarnya pembinaan perfoma guru dalam mengelola proses belajar mengajar didesain dengan praktis serta rasional. Baik desainnya maupun pelaksanaannya dilakukan atas dasar analisis data mengenai kegiatankegiatan di kelas. Data dan hubungan antara supervisor/kepala sekolah dan guru merupakan dasar program, prosedur, dan strategi pembinaan mengajar guru 
dalam mengembangkan pembelajaran murid-murid. Dengan demikian dapat disimpulkan bahwa supervisi klinis merupakan salah satu bentuk supervisi yang dilakukan terhadap guru dengan memenuhi kriteria sebagai berikut; (1) Bantuan atau bimbingan kepala sekolah yang dilakukan secara profesional terhadap guru berkenaan dengan perbaikan pengajaran yang mereka lakukan baik yang sudah memenuhi target/yang sudah tercapai maupun yang belum tercapai, (2) Didasarkan atas permintaan guru yang bersangkutan ataupun permintaan dari kepala sekolah dengan persetujuan dan kerelaan dari guru yang bersangkutan dan sudah tersedia program pengajaran yang akan disupervisi oleh kepala sekolah, (3) Melalui siklus yang sistimatik yakni dimulai dengan pertemuan awal, observasi kelas yang cermat, dan kajian balikan yang sesegera dan seobyektif mungkin tentang penampilan mengajarnya yang nyata, (4) Fokus observasi/pelaksanaan kepala sekolah dan bantuan yang diberikan sesuai dengan rancangan program guru yang akan dilaksanakan dalam proses pembelajaran dikelas.

Langkah-langkah supervisi klinis dilaksanakan secara bertahap, tahap pertama pertemuan awal, tahap kedua observasi kelas, dan tahap ketiga pertemuan akhir/diskusi data hasil observasi. Di Sekolah Dasar Negeri Catak Gayam 02 supervisi klinis dilaksanakan atas dasar teori tersebut yang mana program kegiatan supervisi telah disusun, dan langkah-langkah supervisi klinis secara berurutan.

Berdasar hasil temuan peneliti supervisi klinis dilaksanakan secara bertahap yaitu; Tahap pertama merupakan pertemuan awal. Pada tahap ini yang terpenting diperhatikan oleh kepala sekolah adalah harus dapat menciptakan suasana yang akrab, terbuka dan penuh kekeluargaan, karena merupakan kunci pokok terhadap keberhasilan supervisi.. Jadi yang terjalin adalah hubungan kologial dalam suasana kerjasama yang harmonis. Pada kegiatan/tahap ini supervisor/kepala sekolah mempunyai tugas antara lain: 1) membangun hubungan atas dasar saling percaya dan saling membantu, dan 2) menjadikan guru untuk dapat berperan co-supervisor. Membicarakan rencana ketrampilan yang akan diobservasi dan dicatat, serta memberikan kesempatan kepada guru dan supervisor untuk mengidentifikasi perhatian utama guru kemudian menterjemahkan ke dalam bentuk tingkah laku yang diamati dapat dilakukan pada tahap awal ini. Pelaksanaan pertemuan pendahuluan juga membicarakan, dan menentukan pelajaran atau unit-unit pengajaran secara inten, yaitu meliputi 
188 | TAZKIR: Jurnal Penelitian Ilmu-ilmu Sosial dan Keislaman

Vol. 02 No. 2 Desember 2016

pikiran tujuan atau hasil yang ingin dicapai, materinya, strategi pengajarannya, kegiatan belajar-mengajar, sumber bahan pelajaran, antisipasi terhadap masalahmasalah yang diperkirakan akan dihadapi dan proses serta alat atau instrumen evaluasinya.

Hubungan yang baik antara supervisor/kepala sekolah harus sudah baik terbentuk sebelum supervisor mengadakan observasi dalam kelas.

Suwarna mengemukakan bahwa secara teknis diperlukan lima langka utama bagi terlaksananya pertemuan pendahuluan yang baik, yaitu: Menciptakan suasana intim dan terbuka antara supervisor dan guru sebelum langkah-langkah selanjutnya dibicarakan, membicarakan rencana pelajaran yang telah dibuat oleh guru yang mencakup tujuan, bahan, kegiatan belajar mengajar, serta alat evaluasinya, mengidentifikasi komponen keterampilan (beserta indikatornya) yang akan dicapai oleh guru dalam kegiatan mengajar/latihan praktek mengajar tersebut, misalnya guru yang berlatih menguasai keterampilan bertanya,, mengembangkan atau memilih instrumen observasi yang akan digunakan, merekam data dalam penampilan guru sesuai dengan persetujuan dan kesepakatan tentang keterampilan beserta indikatornya, instrumen observasi yang dipilih atau yang akan dikembangkan, dibicarakan bersama antara guru dan supervisor.

Tahap kedua observasi kelas dilakukan kepala sekolah dan guru. Observasi kelas ini harus dilakukan setelah hubungan kesejawatan terbentuk, rencana pelajaran dan rencana observasi telah disetujui bersama. Dengan kata lain observasi kelas dapat dilaksanakan dengan baik apabila kedua belah pihak kepala sekolah dan guru telah sepakat, telah mengadakan konsensus untuk kontak. Kesepakatan ini sangat diperlukan untuk menghindari hal-hal yang dapat mengganggu proses pencapaian tujuan supervisi. Dalam tahap ini guru mengajar dengan menerapkan komponen-komponen ketrampilan yang telah disepakati pada pertemuan awal. Sementara itu kepala sekolah mengadakan observasi dengan menggunakan alat yang juga telah di sepakati bersama pada pertemuan awal, untuk mencari dan memperoleh data yang obyektif terjadi pada saat guru mengajar didepan kelas. Kepala sekolah masuk kelas tanpa mengganggu jalannya proses pembelajaran. Beliau mengambil tempat duduk di belakang siswa, sehingga pembelajaran akan berjalan seperti biasanya. Fungsi utama observer pada tahap ini adalah menangkap apa yang terjadi selama pelajaran berlangsung secara lengkap, agar supervisor dan guru dapat dengan 
tepat mengingat kembali hal-hal yang terjadi dalam pembelajaran sebelumnya. Adapun tujuan dari kunjunngan kelas adalah agar analisis dapat dibuat subyektif mungkin, dan ide pokok dalam observasi ini adalah mencakup apa yang terjadi selama pelajaran berlangsung sehingga dapat digunakan dalam analisis dan komentar.

Suwarna mengemukakan hal-hal yang harus dilakukan pada saat pelaksanaan observasi antara lain guru mengajar berdasarkan komponen ketrampilan yang telah disepakati dalam pertemuan pendahuluan. Dipihak lain supervisor mengamati dan mencatat atau merekam tingkah laku guru ketika mengajar. Supervisor juga dapat mengadakan observasi dan mencatat tingkah laku siswa di kelas serta interaksi siswa dengan guru. Untuk lebih jelasnya langkah-langkah pada tahap observasi kelas peneliti simpulkan: Kepala sekolah mencatat hasil observasi, sesuai dengan pedoman instrumen yang telah dipersiapkannya, kepala sekolah juga mencatat temuan-temuan lain diluar instrumen yang sudah disiapkan, setelah berakhir kegiatan observasi kelas kepala sekolah berusaha membuat rumusan hasil observasinya dan memperkirakan bantuan atau perbaikan yang akan diberikan kepada guru yang disupervisi, kapala sekolah juga memperkirakan penguatan terhadap hal yang sudah dilakukan dengan benar dalam proses pengajaran yang sudah dilakukan oleh guru.

Tahap ketiga analisis data observasi kelas dilakukan kepala sekolah dalam rangka untuk mengetahui secara pasti permasalahan yang timbul dan dapat memperoleh gambaran dan penafsiran sementara tentang perilaku guru didepan kelas. Dalam analisa data ini kepala sekolah melakukan tanpa bersama guru, dan dilakukan pada saat jam istirahat setelah melakukan observasi kelas. Sesegera mungkin kepala sekolah melakukan analisa data. Pada tahapan ini Suwarna berpendapat bahwa; Hasil observasi berdasarkan pengamatannya ketika menilai ketrampilan guru mengajar di kelas, hasil observasi yang ada dianalisis dan dimaknai oleh kepala sekolah, sehingga dapat digunakan sebagai bekal diskusi dengan guru, kepala sekolah dapat mengetahui kekurangan/kelemahan guru yang harus diperbaiki hal ini dapat digunakan sebagai bahan diskusi dengan guru pada tahap berikutnya, kepala sekolah tidak memihak antara guru yang satu dengan yang lainnya, dan menggunakan keakuratan data yang disesuaikan dengan program pelaksanaan pembelajaran 
190 | TAZKIR: Jurnal Penelitian Ilmu-ilmu Sosial dan Keislaman

Vol. 02 No. 2 Desember 2016

guru yang bersangkutan sebagai koreksi perbaikan terhadap supervisi yang dilaksanakan.

Tahap keempat pertemuan akhir/diskusi data hasil observasi kelas. Pertemuan akhir ini berbeda dengan pertemuan awal yang dapat dilangsungkan beberapa jam, bahkan sehari atau lebih sebelum kegiatan mengajar dilakukan. Pertemuan akhir harus dilangsungkan dengan segera sesudah kegiatan mengajar selesai. Hal ini untuk menjaga agar segala sesuatu yang terjadi masih segar dalam ingatan kepala sekolah maupun guru yang di supervisi, serta sesuai pula dengan pendekatan kompetensi yang menuntut pemberian balikan segera. Pertemuan akhir ini merupakan kesepakatan untuk bertukar pikiran antara guru dan supervisor tentang apa yang ingin dicapai, dan apa yang terjadi dikelas. Keberhasilan ini tergantung pada seberapa jauh proses supervisi klinis tersebut dipandang sebagai proses pengembangan, pokok evaluasi yang dimaksutkan mengerti dan mengacu pada perkembangan kemampuan profesional. Pada umumnya pertemuan ini merupakan diskusi balikan antara kepala sekolah dan guru. Suasana pertemuan sama dengan pertemuan awal, yaitu suasana akrab, bebas dari suasana menilai ataupun mengadili. Kepala sekolah menyajikan data sedemikian rupa, sehingga guru dapat menemukan kekurangan dan kelebihannya sendiri. Disinilah kepala sekolah dituntut kesabarannya, sehingga tidak terjerumus untuk menilai, mengadili, ataupun mendikte guru. Titik tolak pertemuan ini adalah kontrak yang telah disepakati pada pertemuan awal, dan pada akhir pertemuan guru diharapkan menyadari seberapa jauh kontrak yang telah dibuatnya atu dapat dicapai. Berdasar hasil diskusi ini, kontrak berikutnya dapat dibuat. Pada pertemuan akhir ini kepala sekolah memberikan kesempatan yang luas kepada guru untuk memberikan tanggapan terhadap data hasil observasi dan gambaran yang diberikan kepala sekolah. Dalam hal ini kepala sekolah bertindak sebagai fasilitator dan selalu memberikan pengakuan terhadap keberhasilan guru, sehingga guru merasakan kepuasan atas pelayanan yang diberikan kepala sekolah. Pada tahap ini beberapa yang harus diperhatikan yaitu: memberi penguatan, mengulas kembali tujuan pembelajaran, mengulas kembali hal-hal yang telah disepakati bersama, mengkaji data hasil pengamatan, tidak bersifat menyalahkan, data hasil pengamatan tidak disebarluaskan, penyimpulan, hindari saran secara langsung, dan merumuskan kembali kesepakatan-kesepakatan sebagai tindak lanjut proses perbaikan. 
Hal diatas sesuai dengan ungkapan dari Sukirman (1998: 89-90) dalam pelaksanan supervisis klinis melalui empat tahap yaitu: pra observasi, observasi kelas, analisis hasil observasi, dan pembicaraan hasil observasi.

Sedangkan Sahertian ${ }^{12}$ memberikan tiga tahapan dalam pelaksanaan supervisi klinis diantaranya adalah: 1) Tahap pertama pertemuan awal, dalam percakapan awal ini seorang guru mengeluh bahwa pada saat melaksanakan tugas mengajar dikelas menemui kendala yang sulit untuk dipecahkan sendiri. 2) Tahap ke dua observasi, dan 3) tahap ini merupakan kegiatan akhir, yaitu percakapan setelah analisis dilakukan, ini terjadi antara supervisor dengnan guru.

Efendi $^{13}$ menyatakan ada delapan tahapan siklus supervisi klinis sebagai berikut: 1) Supervisor mengembangkan hubungan dengan guru. Fase ini sangat penting, karena keberhasilan menjalin hubungan antara supervisor/kepala sekolah dengan guru. 2) Supervisor dan guru bersama-sama menyusun rencana pelajaran. 3) Supervisor dan guru merencanakan observasi kelas. 4) Mengadakan observasi kelas. 5) Menganalisa proses belajar mengajar. 6) Merencanakan strategi pertemuan. 7) Pertemuan ini merupakan kesepakatan untuk bertukar pikiran antara guru dan supervisor tentang apa yang ingin dicapai dan apa yang terjadi dikelas. 8) Merencanakan tindak lanjut ( follow up)

Ketika berbicara tentang langkah-langkah supervisi klinis di sini Sergiovani dalam Efendi mengemukakan proses pelaksanaan supervisi klinis tidak harus diikuti oleh setiap supervisor dalam mengimplementasikan supervisi klinis. Setiap tahap atau fase tergantung pada sifat dari aktifis kelas, maksud dan tujuan khusus supervisi, tingkat kemampuan guru dan supervisor. Supervisor dapat menentukan prosedur yang applicable dan relevan dengan keunikan situasi kelas dan guru yang dihadapi.

Pada penelitian skripsi Daya Negeri Wijaya dalam judul Peningkatan Kemampuan Guru dalam Menyusun Rencana Pelaksanaan Pembelajaran melalui Supervisi Klinis (2011) mengatakan pada kesimpulannya bahwa; 1) penerapan supervisi klinis untuk meningkatkan kemampuan guru dalam menyusun RPP terbagi menjadi tiga siklus, dalam setiap siklus berhasil melaksanakan apa yang

\footnotetext{
${ }^{12}$ Sahartian Piet A, Konsep Dasar dan Teknik Supervisi Pendidikan. (Jakarta: Reneka Cipta, 2000), hlm. 40 .

${ }^{13}$ Effendi H. A.R. 2001. Supervisi Klinis. Malang: Makalah di sajikan dalam Pelatihan Kepala Madrasah Tsanawiyah se Kabupaten Malang.
} 
192 | TAZKIR: Jurnal Penelitian Ilmu-ilmu Sosial dan Keislaman

Vol. 02 No. 2 Desember 2016

mereka rencankan sendiri mulai dari tahap pendahululan, observasi, dan umpan balik dengan lancar, 2) supervisi klinis dapat meningkatkan kemampuan guru, hal ini dapat dilihat dari perubahan ke arah yang lebih baik.

Kepala sekolah memberikan dorongan kepada guru untuk meningkatkan kinerjanya, kepala sekolah Sekolah Dasar Negeri Catak Gayam 02 dalam memberikan dorongan kepada guru untuk meningkatkan kenerjanya. Sebagai motivator, kepala sekolah harus memiliki strategi yang tepat diantaranya mengedepankan komunikasi kebawah, arif, terbuka, serta berjiwa besar setiap menghadapi masalah, dan memberi motivasi kepada para guru agar terus berusaha meningkatkan kinerjanya. Memberikan motivasi terhadap guru juga dengan pemberian penghargaan yang dapat menumbuhkan inisiatif, kemampuan-kemampuan kreatif, dan semangat kompetisi yang sehat. Penghargaan ini sangat penting untuk meningkatkan mutu kinerja guru, dan untuk mengurangi kegiatan yang kurang produktif. Upaya yang dapat dilakukan kepala sekolah dalam meningkatkan kinerjanya, khususnya dalam meningkatkan kinerja guru, dapat didiskripsikan sebagai berikut: (1) Mengikutsertakan para guru dalam penataran atau pelatihan untuk menambah wawasannya, memberikan kesempatan kepada guru-guru untuk meningkatkan pengetahuan dan ketrampilan dengan belajar ke jenjang yang lebih tinggi, (2) Menggunakan waktu belajar secara efektif di sekolah dengan cara mendorong para guru untuk memulai dan mengakhiri pelajaran sesuai waktu yang telah ditentukan, serta memanfaatkannya secara efektif dan efisien untuk kepentingan pembelajaran, dan sebagainya, (3) Memberi dorongan dan penghargaan secara efektif dan penyediaan berbagai sumber belajar melalui pengembangan pusat sumber belajar.

Dalam mewujudkan bahwa motivasi merupakan suatu kondisi yang menggerakkan manusia kearah suatu tujuan, kepala sekolah memberikan dorongan dengan mengedepankan kemampuan berkomunikasi yang baik dengan para guru, selalu sikap terbuka dalam segala hal, dan bersikap arif dalam memandang semua permasalahan yang muncul adalah permasalahan bersama yang harus diselesaikan secara bersama pula. Sehingga dapat mengatasi semua permasalahan dengan baik dan dapat menumbuhkan semangat kerja yang tinggi. Dengan penampilan atau perilaku kepala sekolah yang selalu memperhatikan dan menghargai orang lain dalam memberikan motivasi, maka 
akan tumbuh kesadaran yang sangat mendalam pada diri guru untuk terus berusaha memperbaiki dan meningkatkan kemampuan kinerjanya.

Wiles dalam bukunya "The Supervisor's role has bicome supporty, assisting, rather directing", dalam hal ini memberikan peran kepala sekolah dalam tiga hal: 1) kepala sekolah berperan membantu guru dalam memecahkan masalah sendiri serta dapat berusaha meningkatkan kinerjanya sebagai guru, 2) berperan dalam memberikan dorongan (support) kepada para stafnya selalu berusaha mengembangkan kemampuan dibidangnya masing-masing, dan 3) selalu mengikutsertakan bawahannya dalam memecahkan masalah sendiri dan mengembangkan kemampuannya.

Peran kepala sekolah dalam membantu guru dalam memecahkan masalah yang dihadapi. kepala sekolah memberikan bantuan kepada guru berdasarkan hubungan kemanusiaan (human relation) dengan memandang guru sebagai :manusia yang bulat (whole people) yang memiliki hak-hak pribadi bukan sekedar paket energi, ketrampilan, dan sikap-sikap yang dibutuhkan para manajer, administrator atau supervisor. Menurut Wiles menjelaskan bahwa peran kepala sekolah sebagai supervisor pada tiga hal yaitu: (1) kepala sekolah berperan dalam membantu para guru agar dapat memecahkan masalah sendiri serta dapat selalu berusaha meningkatkan kemampuan kinerjanya sebagai guru, (2) sebagai konsultan ia dapat memberikan dorongan kepada para stafnya agar selalu berusaha mengembangkan kemampuannya dibidang masing-masing, (3) kepala sekolah selalu mengikut sertakan bawahannya/para guru dalam memecahkan masalahnya sendiri dan mengembangkan kemampuannya.

Di Sekolah Dasar Negeri Catak Gayam 02 tempat penelitian peneliti kepala sekolah dalam memberikan bantuan kepada guru dilakukan dengan cara menciptakan suasana yang sangat akrab dan santai. Beliau sangat jeli terhadap perubahan-perubahan perilaku guru yang memiliki masalah. Untuk memperoleh informasi yang jelas dari guru, kepala sekolah selalu memberi umpan dengan menceritakan masalah yang pernah dihadapi. Dengan demikain guru tidak merasa malu untuk menceritakan apa yang sedang dialami. Hal ini merupakan dasar dalam memberikan bantuan pemecahan masalah, sehingga guru dapat memecahkan masalahnya sendiri dan dapat mengembangkan kemampuannya. Kepuasan guru dengan terlihat dalam menjalankan tugasnya menunjukkan kepada mereka sebagai manusia, dengan kata lain kepala sekolah selalu mengorangkan orang (guru) dan membantu untuk memecahkan 
194 | TAZKIR: Jurnal Penelitian Ilmu-ilmu Sosial dan Keislaman

Vol. 02 No. 2 Desember 2016

permasalahan yang dihadapi. Kepala sekolah selalu memberikan saran dan pendapatnya dalam membantu guru serta terus memberikan motivasi agar guru terus berusaha menyelesaikan permasalahannya sendiri dengan baik dan mengemnbangkan kemampuan profesionalnya.

Kendala-kendala yang dihadapi dalam pelaksanaan supervisi klinis di Sekolah Dasar Negeri Catak Gayam 02 Kabupaten Jombang, setiap kegiatan yang dilakukan manusia tidak akan lepas dari suatu permasalahan yang dapat mengganggu kelancaran pelaksanaan kegiatan itu sendiri, walaupun pengaruh terhadap keberhasilan pelaksanaan kegiatan tidak terlalu berarti, namun tetap dicarikan jalan pemecahannya.

Pelaksanaan supervisi klinis yang dilakukan kepala sekolah Sekolah Dasar Negeri Catak Gayam 02 tidak lepas dari permasalahan yang dapat menghambat supervisi klinis. Dari hasil wawancara diperoleh keterangan bahwa kendala yang muncul dalam pelaksanaan supervisi klinis adalah; (1) Kepala sekolah sering dinas luar (rapat dinas) baik yang dilakukan dikantor Wilayah Propinsi Jawa timur, Dinas Pendidikan Kabupaten Lumajang, Kelompok Kerja Kepala Sekolah (KKKS) di Kabupaten Jombang, dan rapat-rapat dinas di Kecamatan Mojowarno. Pada kendala ini kepala sekolah mengatasi dengan memanfaatkan waktu senggangnya. Jam-jam istirahat digunakan ibu kepala sekolah dalam menganalisas data hasil observasi, (2) Adanya persepsi guru yang masih menganggap kegiatan supervisi sebagai cara kepala sekolah untuk mencari tahu kelemahan dan kekurangan guru sebagai alasan untuk menekan guru. Persepsi guru yang negatif ini diatasi kepala sekolah pada saat pertemuan awal, beliau menerangkan tujuan supervisi dengan cara kekeluargaan, tanpa ada jarak antara kepala sekolah dengan guru yang diobservasi, sehingga guru akan sangat senang dan memahami dari tujuan supervisi klinis, (3) Kendala juga terjadi dikalangan siswa, saat dilaksanakan observasi kelas yang mengannggap kehadiran kepala sekolah di kelasnya merupakan bentuk ketidak percayaan kepada kemampuan guru dalam melaksanakan tugas mengajar. Anggapan ini diatasi oleh guru dengan membari penjelasan bahwa kepala sekolah ikut saat kita belajar ingin melihat kita dari dekat dan bersedia membantu jika ada kesulitan. Dengan penjelasan dari guru akhirnya siswa merasa senang dan nyaman, tanpa ada rasa cemas.

Semua permasalahan yang timbul dapat diselesaikan dengan baik melalui kerja sama yang dibangun kepala sekolah dengan mengedepankan 
komunikasi yang intensif, baik dengan guru, staf tata usaha, maupun dengan para siswa, sehingga fungsi dan peran kepala sekolah sebagai supervesor yang dilakukan di Sekolah Dasar Negeri Catak Gayam 02 Kabupaten Jombang betulbetul sesuai harapan bersama untuk meninggkatkan kinerja para guru sehingga prestasi siswa sesuai dengan harapan.

Disamping itu guru yang sudah di supervisi akan lebih meningkatkan perbaikan secara berkesinambungan sebagai tindak lanjut supervisi klinis yang dilakukan kepala sekolah guna peningkatan sebagai guru yang profesional.

Berdasarkan hasil analisa dari pembahasan penelitian ini, apabila dikaitkan dengan pengembangan teori dari Sahertian dan Efendi, dimana langkah-langkah pada pelaksanaan supervisi klinis tidak adanya analisa data yang dilakukan kepala sekolah/superviosor, maka penelitian ini merupakan perbaikan dari tindak lanjut teori langkah-langkah supervisi klinis, yang mana sebelum pelaksanaan diskusi analisa hasil observasi supervisor/kepala sekolah menganalisa sendiri hasil observasi kelas tanpa bersama guru dengan cermat, dan hati-hati, serta mempersiapkan perbaikan apa yang harus dilakukan oleh guru.

Penelitian terdahulu yang merupakan penguat dari penelitian ini menyatakan bahwa pelaksanaan supervisi (supervisi klinis) yang merupakan tindakan supervisi yang dilakukan oleh kepala sekolah/supervisor sangatlah efektif dalam meningkatkan kinerja guru sebagai guru yang profesional. Hal ini dapat dibuktikan dari beberapa peningkatan prestasi guru dan siswa pada Sekolah Dasar Negeri Catak Gayam 02 Kabupaten Jombang.

\section{PENUTUP}

\section{Kesimpulan}

Berdasarkan uraian dan hasil penelitian yang peneliti lakukan beserta pembahasan tentang peran kepala sekolah dalam melaksanakan supervisi klinis, dapat ditarik kesimpulan sebagai berikut: Tahapan pelaksanan supervisi klinis di Sekolah Dasar Negeri Catak Gayam 02 dilaksanakan secara bertahap.

Tahapan pelaksanan supervisi klinis di Sekolah Dasar Negeri Catak Gayam 02 dilaksanakan berdasarkan program kerja kepala sekolah dibidang kepengawasan (supervisi klinis). Supervisi klinis dilaksanakan secara bertahap, proses pentahapan dilakukan oleh kepala sekolah bersama bapak ibu guru Sekolah Dasar Negeri Catak Gayam 02 serta sesuai dengan makna supervisi klinis mengacu pada efektifitas dan efesiensi dalam membantu guru untuk 
196 | TAZKIR: Jurnal Penelitian Ilmu-ilmu Sosial dan Keislaman

Vol. 02 No. 2 Desember 2016

memecahkan permasalahan yang dihadapinya, mendorong guru untuk meningkatkan kinerjanya. Pentahapan dalam pelaksanaan supervisi klinis ini sangat penting adanya, dalam rangka mengefektifkan pelaksanaan supervisi klinis, sehingga tujuan untuk membantu guru, mendorong guru untuk memecahkan dan meningkatkan kemampuannya dapat terlaksana dan berhasil sesuai dengan harapan. Keefektifan supervisi klinis yang dilaksanakan di Sekolah Dasar Negeri Catak Gayam 02 sebagai program supervisi yang disusun secara bersama dan merupakan acuan pelaksanaan supervisi, dapat dilaksanakan secara efektif dan efisien, pertemuan awal dari pelaksanaaik, dan menyenangkan. Sehingga merubah atau membawa pola pikir guru yang menganggap negatif terhadap pelaksanaan supervisi klinis, menjadikan supervisi sebagai kebutuhan dalam memecahkan suatu permasalahan dan mengembangkan kemampuan profesionalnya, pelaksanaan observasi kelas dapat dilaksanakan kepala sekolah bersama guru dan siswa dengan cukup baik walaupun dikalanngan siswa masih ada anggapan yang tidak mendukung terhadap pelaksanannya, tetapi semuanya dapat diatasi dengan baik, kegiatan analisa data hasil observasi kelas yang dilakukan kepala sekolah dapat dilakukan dengan baik, walaupun tanpa melibatkan guru.

\section{Saran}

Bertitik tolak dari temuan penelitian ini, ada beberapa saran dari peneliti dengan harapan pelaksanaan supervisi di sekolah dapat lebih efektif pelaksanaannya, mengingat pentingnya supervisi klinis dalam membantu dan mendorong guru untuk terus mengadakan perubahan yang positif dalam tugasnya. Saran yang diajukan penulis yaitu: (1) penyusunan program supervisi oleh sekolah hendaknya disesuaikan dengan jadwal kegiatan dinas pendidikan setempat yang melibatkan kepala sekolah, (2) untuk menghilangkan persepsi yang negatif terhadap pelaksanaan supervisi klinis dikalangan guru disamping dengan memberikan penjelasan, sekolah juga diharapkan menyediakan literatur yang berkaitan dengan kesupervisian, (3) kepala sekolah hendaknya mensosialisasi secara langsung kepada siswa tentang tujuan dilaksanakannya observasi kelas, (4) dinas setempat untuk dapat menganjurkan kepada para sekolah untuk betul-betul melaksanakan supervisi klinis, (5) pelaksanaan supervisi klinis agar lebih efektif dapat melibatkan pihak-pihak lain yaitu: komite sekolah, maupun wali murid, (6) untuk semua sekolah diharapkan 
melakukan supervisi klinis, karena dapat dijadikan perubahan untuk perbaikan kinerja guru, dan (7) untuk sekolah yang sudah menerapkan kegiatan ini, lebih ditekankan pada pemberian solusi dan motivasi agar kesulitan-kesulitan yang dihadapi penanganannya dapat sesuai dan tidak memberatkan kegiatan para guru. 
198 | TAZKIR: Jurnal Penelitian Ilmu-ilmu Sosial dan Keislaman

Vol. 02 No. 2 Desember 2016

\section{DAFTAR RUJUKAN}

Arikunto, S. 2006. Prosedur Penelitian Suatu Pendekatan Praktik. Jakarta: PT Cipta Karya.

Bogdan, R.C. \& Biklen, S. Knoop.1982. Qualitative Research For Education: an Introduction to Theory and Metho. Unitet States Of America.

Bakri, Masykuri. 2013. Metode Penlitian Kualitatif Pendekatan Teoritis dan Praktis. Jakarta: Nirmana Press.

Effendi H. A.R. 2001. Supervisi Klinis. Malang: Makalah di sajikan dalam Pelatihan Kepala Madrasah Tsanawiyah se Kabupaten Malang.

Faesal, Sanafiah. 1990. Penelitian Kualitatif Dasar-Dasar dan Aplikasi. Malang: Yayasan Asih Asuh.

Lucio, William H. \& McNeil, John D. 1979. Supervision in Throught and action. 3 id. Ed. New York: McGrow-hill Book CO.

Milles, M.B. \& Humerman, A.M., 1992. Analisis Data Kualitatif. Bandung: Remaja Rosdakarya.

Quinn, Pathon Michael. 2000. Qualitatif Evaluation Methods. Sage Publication. Baverly Hills.

Riyanto, Yatim. 2007. Metodologi Penelitian Pendidikan Kualitatif. Surabaya: UNESA University Press.

Sahartian Piet A, 2000. Konsep Dasar dan Teknik Supervisi Pendidikan. Jakarta: Reneka Cipta.

Siagian, H. 1995. Manajemen Suatu Pengantar. Bandung: Alumni

Suprayogo, Imam. 2001. Metodologi Penelitian Agama. Bandung Rosdakarya.

Thoha, Mifta. 1995. Kepemimpinan Dalam Manajemen. Jakarta: Rajawali Press

Wiriaatmadja, Rochiati. 2009. Metode Penelitian Tindakan Kelas. Bandung. Remaja Rosdakarya 